ROCZNIKI FILOZOFICZNE

Tom LXVII, numer $1-2019$

DOI: http://dx.doi.org/10.18290/rf.2019.67.1-6

PAWEŁ PIJAS

\title{
ARETOLOGICZNA INTERPRETACJA (CHRZEŚCIJAŃSKIEJ) WIARY RELIGIJNEJ
}

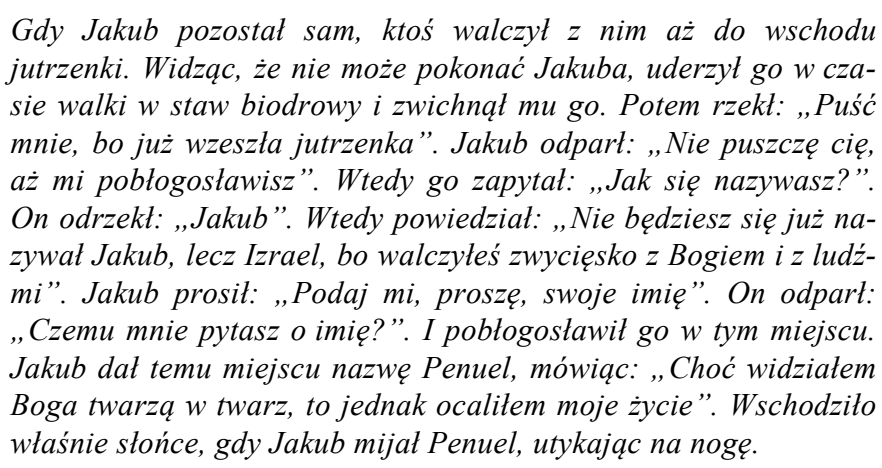

$(\operatorname{Rdz} 32,25-32)^{1}$

1.

Filozofia religii uprawiana w kontekście chrześcijaństwa ${ }^{2}$ często sprowadza się do teologii naturalnej. Jej przedmiotem jest racjonalne uzasadnienie lub racjonalna krytyka przekonań religijnych wyrażających doktrynę tej religii. Do klasycznych zagadnień należą tutaj m.in. następujące problemy: wiarygodność i spójność teizmu, natura Boga i Jego atrybutów czy też

Dr PaweŁ PIJAS — adiunkt Zakładu Historii Filozofii Starożytnej, Średniowiecznej i Nowożytnej, Instytut Filozofii, Socjologii i Dziennikarstwa Uniwersytetu Gdańskiego, absolwent Kolegium MISH KUL i Wydziału Filozofii KUL; adres do korespondencji - e-mail: pawel. pijas@ug.edu.pl. ORCID: https://orcid.org/0000-0002-7694-7482.

* Tekst artykułu jest rozszerzoną wersją dwóch wystąpień („Bóg, wiara i schematy poznawcze”, 22-25.09.2016, Kazimierz Dolny; „Próba konceptualizacji wiary religijnej”, 13-14.10.2017, Gdańsk-Leźno). Pewne wątki zawdzięczam dyskusji wokół tekstu Prof. Ireneusza Ziemińskiego „Kryzys chrześcijaństwa z perspektywy filozofii religii” (=ZIEMIŃSKI 2014), opublikowanej w czasopiśmie Filo-sofija (= ZIEMIŃSKI 2016).

${ }^{1}$ Wszystkie odniesienia biblijne pochodzą z Pismo Święte Starego i Nowego Testamentu (Częstochowa: Edycja Świętego Pawła, 2009).

${ }^{2}$ Ograniczam zakres mojej wypowiedzi do chrześcijaństwa (katolickiego), konkluzje tekstu mogą jednak sięgać dalej, przynajmniej o tyle, o ile rozważamy religie monoteistyczne. 
teodycea. Tak rozumianą filozofię religii cechuje swoisty intelektualizm, w żargonie zaś współczesnej filozofii analitycznej - kognitywistyczna interpretacja języka religijnego, który traktuje się jako wyraz życia religijnego dostępny obiektywnej analizie ${ }^{3}$. Złożony i bogaty treściowo fenomen wiary religijnej ${ }^{4}$ jest tutaj analizowany głównie pod kątem zawartości propozycjonalnej, ujętej $\mathrm{w}$ formie quasi-teorii, uporządkowanego logicznie i przedmiotowo zbioru sądów, ocenianego przez pryzmat logicznych, epistemologicznych i metodologicznych kanonów. Niewątpliwie doktryna jest ważnym komponentem wiary. Nie można jednak zredukować wiary do (władzy przyjęcia) doktryny, a i tę trudno uznać za ścisły odpowiednik teorii, formułowanych w filozofii czy na gruncie nauk przyrodniczych.

Trudno się dziwić, że intelektualizm głównego nurtu filozofii religii wzbudzał i wzbudza kontrowersje. Już dawno sformułowano pod adresem refleksji tego typu zarzut, że nie dotyczy ona Boga chrześcijaństwa, istoty, którą czczą chrześcijanie, lecz wypowiada się o Bogu filozofów, konstrukcie teoretycznym, będącym odpowiedzią na spekulatywne potrzeby poznawcze ${ }^{5}$. $\mathrm{Ci}$, których przekonuje ten zarzut, często popadają w inne kłopotliwe stanowisko. Można je nazwać intelektualizmem kontrfaktycznym ${ }^{6}$ lub antyintelektualizmem, w żargonie współczesnej filozofii analitycznej: antykognitywistyczną interpretacją języka religijnego. Ponieważ w gruncie rzeczy trudno traktować przyjęcie wiary jako uznanie teorii, gdyż taka asercja nie wytrzymuje „krytyki czystego rozumu”, którą mogą przetrwać nasze najlepsze teorie naukowe, powinniśmy w ogóle zapomnieć o poznawczych pretensjach i doktrynalnym komponencie wiary. Powinniśmy uznać ją przede wszystkim za formę praktyki. Utożsamić z aktywnością społeczną, grą językową czy wyborem egzystencjalnym, źródłami „religijnego obrazu świata", który nadaje sens naszemu życiu. Podobnie jak w poprzednim przypadku można odnieść wrażenie, że antyintelektualizm w filozofii religii zakłada jednostronne rozumienie wiary. $\mathrm{Z}$ pewnością ważnym aspektem wiary są jej rozmaite praktyczne korzyści, na przykład generowanie dodatkowej motywacji do moralnie dobrych działań. Niemniej, trudno właściwie

\footnotetext{
${ }^{3}$ Intelektualizm (kognitywizm) zakłada znaczna część autorów zajmujących się filozofią religii, a literatura przedmiotu jest ogromna. Wymieniam kilka prac: DAVIES 2006; KeNNY 1992; Plantinga i WolterstorfF (eds) 2004; BRÜNTRUP i TACELli (eds.) 1999.

${ }^{4}$ Ze względu na ekonomię tekstu w dalszych partiach będę używał krótszej formy „wiara”.

${ }^{5}$ Autorem tego zarzutu jest Blaise Pascal. Współcześnie antyintelektualizm cechuje m.in. filozofię religii nawiązującą do Wittgensteina II. Na gruncie polskim zbliżone poglądy głosił Leszek Kołakowski. Zob. KoŁAKOWSKi 1990; WitTGenstein 1967; Moser 2016, 5-20.

${ }^{6}$ Proponuję to określenie w nawiązaniu do metafilozofii Bernarda Williamsa - WiLliams $2017,325-350$.
} 
powiedzieć, dlaczego miałbym traktować wiarę jako poważną „,egzystencjalną propozycję" lub uważać ją za grę językową wartą mojego czasu, gdybym nie był przekonany o prawdziwości powiązanych z nią sądów. Oba stanowiące bazę konceptualną filozofii religii modele wiary mogą wzbudzać swoją jednostronnością opór u człowieka religijnego. Wydaje się, że mogą istnieć racje, aby uznać obydwa podejścia za ograniczone i redukcyjne, a być może za całkiem błędne.

Zasugerowałem, że oba modele są ograniczone, chciałbym teraz rozwinąć i uzasadnić to przekonanie. $Z$ perspektywy osób autentycznie zaangażowanych w chrześcijańskie życie religijne, „kompetentnych osób wierzących ${ }^{7}$, wiara nie może być sprowadzona ani do (władzy przyjęcia) doktryny, ani też do komponentu praktycznego. W praktyce duszpasterskiej (ale nie tylko KENNY 1992, 4, 48) odróżnia się wiarę bliską światopoglądowi, przejętą z tradycji lub ograniczoną do mglistych przekonań ${ }^{8}$, i wiarę żywą, która wynika z realnego nawrócenia. Wiara żywa prowadz do całościowej orientacji życia wokół relacji z Bogiem, głębokiej internalizacji zasad moralnych, autentycznego zaangażowania $\mathrm{w}$ religijną praktykę i otwarcia na doświadczenie religijne9. Podobne intuicje wyraża Stanisław Judycki, wyróżniając trzy elementy wiary religijnej:

(1) postawa moralna (bezkompromisowe dążenie do dobra);

(2) przekonanie o istnieniu Boga;

(3) zaufanie do Boga;

Judycki twierdzi, że przez wiarę religijną sensu stricto można rozumieć dopiero przyjęcie (1), (2) i (3) łącznie ${ }^{10}$. Jeżeli intuicje te są trafne, to możemy powiedzieć, że problem intelektualizmu polega na lekceważeniu relacji między (2) a (1) i (3), akceptacja zaś antyintelektualizmu nie pozwala nam na przekonującą interpretację (2) i relacji między (2) a (1) i (3). Wydaje się zatem, że oba nurty cechuje redukcjonizm, który przynajmniej prima facie jest racją za ich odrzuceniem. Redukcjonizm ten prowadzi do prób uchwy-

\footnotetext{
${ }^{7}$ Analogicznie do często używanego argumentu z „kompetentnych użytkowników języka”. Przykładowo zob. MiLLER 2003, 19-20.

${ }^{8}$ Kenny nazywa ją wprost wiarą martwą, chociaż w duszpasterstwie unika się tego określenia, mając nadzieję, że możliwe jest jej ożywienie. Wydaje się, że to właśnie wiara martwa była przedmiotem złośliwych uwag Davida Hume`a, przekonanego, że wierzenia religijne są bliżej niesprecyzowanym, mglistym właśnie przeświadczeniem bez większego wpływu na życie jednostki. Zob.: KenNy 1992, 4, 48; Hume 1962, 216.

9 Zob. KKK, 47-51. Relację między tymi elementami (w nawiązaniu do Św. Tomasza), szczegółowo analizuje AUDi 2014, 327-347.

${ }^{10}$ Jeden z argumentów brzmi: Szatan i jego poplecznicy przyjmują (2), ale uznanie, że Szatan wierzy w Boga w właściwym sensie tego wyrażenia, jest niedorzeczne. JUDYCKI 2014, 57-73.
} 
cenia, opisu i analizy fenomenu wiary przez zainteresowanie tylko fragmentem tego zjawiska, co czyni je nieinteligibilnym, a samą filozofię religii prowadzi do licznych aporii ${ }^{11}$.

Zwolennik intelektualizmu mógłby odpowiedzieć, że jego filozofia religii nie jest redukcyjna, ponieważ świadomie ograniczył się do analizy pewnego aspektu wiary, to jest do badań nad racjonalnym uzasadnieniem niektórych przekonań religijnych ${ }^{12}$. Byłoby to równoważne stwierdzeniu, że racjonalność przekonań religijnych stanowi przedmiot formalny filozofii religii. Zgodnie z klasycznym rozróżnieniem nie można $\mathrm{z}$ tego wnosić, że taka refleksja redukuje wiarę do przekonań, ponieważ przedmiot formalny danej nauki nie jest jej przedmiotem materialnym, pewnym zjawiskiem wraz z całym jego uposażeniem jakościowym. Ta strategia okaże się jednak nieprzekonująca, jeśli uda się wykazać, że wiary nie można tak potraktować, gdyż komponent propozycjonalny jest ściśle złączony z pozostałymi elementami. Gdyby tak było, byłaby to też racja przeciwko drugiemu z omawianych modeli, ponieważ ex hypothesi praktyczny element wiary byłby ściśle powiązany z komponentem propozycjonalnym. W moim przekonaniu świadczą o tym następujące własności wiary religijnej, charakteryzujące ją w przypadku wiary żywej, wiary kompetentnych osób wierzących: (I) transformacja doświadczenia, (II) zależność od woli, (III) relacyjny charakter ${ }^{13}$.

(I) Relację między przekonaniami człowieka wierzącego i człowieka niewierzącego można zinterpretować tak, że drugi zbiór jest podzbiorem pierwszego. Obaj dzielą pewne przekonania, ponieważ przyjmują wiarygodność naturalnych władz poznawczych, informujących ich o światowych obiektach i ich własnościach, lecz wierzący dodatkowo przyjmuje przekonania o rzeczywistości nadprzyrodzonej. Dyskusja między nimi możliwa jest o tyle, o ile poruszają się w obrębie wspólnej przestrzeni epistemologicznej i ontologicznej. Trudno jest jednak zaakceptować powyższą interpretację. Nakłada ona na poznawczą perspektywę wierzącego ramy, w których się nie mieści, ponieważ nie zawiera klarownego podziału na część naturalną i nadprzyrodzoną, gdzie ta ostatnia byłaby niby jakieś dodatkowe piętro gmachu, które jest kaprysem architekta, ale nie zmienia niczego istotnego w konstrukcji budynku. Wyobraźmy sobie na przykład, jak wygląda perspektywa poznawcza osoby przekonanej, że jest powołana do x. Kompetentny

\footnotetext{
${ }^{11} \mathrm{Na}$ temat głównych aporii (tak rozumianej) filozofii religii zob. ZIEMIŃSKI 2013, 263-273.

${ }^{12}$ Dziękuje dr. Błażejowi Gęburze za zwrócenie mojej uwagi na tę kwestię. Zob. DAviES 2006, 11-29.

${ }^{13}$ Traktuję ten rodzaj wiary jako źródłowy, ponieważ pozostałe rodzaje wiary są możliwe o tyle, o ile są przez taką wiarę poprzedzone - nadaje ona sens istnieniu chrześcijaństwa
} 
wierzący uważa, że powołanie się otrzymuje, to dar, który należy przyjąć, bo jest swego rodzaju „najlepszą ofertę egzystencjalną”. Jest taką formą życia, która w największym stopniu zrealizuje potencjał danej osoby i pozwoli jej osiągnąć świętość. Jak wygląda doświadczenie takiej osoby? Gdy przyjrzymy się trudnościom egzystencjalnym w rodzaju poważnego kryzysu małżeńskiego, to okaże się, że spojrzenie wiary może przemienić to doświadczenie, ponieważ nasyca je treścią i znaczeniem, które są nieobecne w ramach porządku naturalnego. Kryzys może okazać się czymś pozytywnym, co stanowi konieczny etap poprzedzający wzrost osobowy lub dojrzewanie samej relacji. Opis i naturalne wyjaśnienie kryzysu będą, rzecz jasna, dalej dostępne dla takiej osoby. Chociaż będzie przejawiała całą gamę zrozumiałych, psychicznych i behawioralnych odruchów, to trzymanie się ich, czyli pozostanie w obrębie naturalnego doświadczenia, nabierze charakteru pokusy, grzesznego zwątpienia w otrzymane powołanie. Kompetentna osoba wierząca odmiennie niż niewierzący konceptualizuje rzeczywistość, posługuje się specyficznym schematem pojęciowym, w którym doświadczenie naturalne odgrywa taką czy inną rolę, lecz nie wyraża całości rzeczywistości, co więcej — nie dotyka jej najważniejszej części. Wiara jest zdolna do transformacji doświadczenia podmiotu tak, że generuje ono odmienną treść propozycjonalną niż u osoby niewierzącej (MACINTYRE 1964, 115-133).

(II) Drugą cechą wiary, która wymyka się omawianym modelom, jest jej woluntarystyczny charakter. W standardowym ujęciu przekonania wyrażają treść propozycjonalną, zależną w ograniczony sposób od decyzji i działań, a mówiąc wprost, wyjąwszy marginalne przypadki ${ }^{14}$, jest ona biernie przyjmowana na podstawie racji poznawczych. Obecność racji pozapoznawczych (np. woli podmiotu) $\mathrm{z}$ epistemologicznego punktu widzenia dyskredytuje przekonanie. Nie musi być tak, że wola nie odgrywa żadnej roli w ludzkim poznaniu, tworzy bowiem i utrwala poznawcze dyspozycje, takie jak otwartość umysłu, dokładność, wytrwałość czy odwaga intelektualna, które nie tylko są gwarantami i mechanizmami korygującymi nasze akty poznawcze, lecz często w ogóle je umożliwiają. Innymi słowy, akty woli są poznawczo istotne, jeżeli odkrywamy dzięki nim nieznane nam racje epistemiczne. Tak dzieje się, gdy wysiłek woli umożliwia podjęcie dalszego badania, zebranie

\footnotetext{
${ }^{14}$ William James pisze o przekonaniach, które potwierdzają się przez akty wiary. Jego propozycja zawiera trafną intuicję dotyczącą natury wiary, lecz w moim przekonaniu pozostaje w ramach paradygmatu intelektualistycznego. Według Jamesa racje praktyczne mają rozstrzygnąć spór, którego konkluzją na poziomie teoretycznym jest agnostycyzm. Zob. JAMES 1996, zwł. 62-88.
} 
nowych danych, krytyczne spojrzenie na obecny stan wiedzy i tak dalej. Nie zmienia to jednak faktu, że akt woli „nie ma mocy” zmiany przekonania o wartości logicznej i zawartości określonej treści propozycjonalnej. Załóżmy, że mam za prawdziwe pewne zdanie. Mogę być przekonany o jego prawdziwości o tyle, o ile dysponuję racjami epistemicznymi, takimi jak oczywiste poznanie niedyskursywne (intuicja), rozumowanie czy opinia racjonalnie uzasadnionego autorytetu. Nie mogę jednak zmienić tego stanu rzeczy samym wysiłkiem woli, jeśli nie prowadzi mnie on do odkrycia nowych racji o takim charakterze. Alternatywą jest tutaj samozakłamanie, ewentualnie fantazja lub myślenie życzeniowe. Nie oznaczają one niestety zmiany przekonania na skutek decyzji, lecz właśnie pretendowanie, że uznana przeze mnie treść propozycjonalna jest inna, niż jest w rzeczywistości, lub folgowanie mechanizmom psychicznym przez które tracę kontakt z rzeczywistością (i z moim poznaniem tej rzeczywistości) (WiLliams 2003, 63-148).

Wiara ma odmienną naturę, gdyż jest ściśle powiązana z aktami woli. Nie tylko dlatego, że obiekt wiary przekracza moje zdolności poznawcze i muszę podjąć decyzję wiary, dysponując ograniczoną wiedzą, lecz i z tego powodu, że akty woli (modlitwa, życie sakramentalne, itd.) przyjmują, rozwijają i pogłębiają wiarę, a ich brak powoduje jej osłabienie i wygasanie. Wierzący musi też pokonywać próby wiary. Nie dotyczą one jednak pytania, czy ktoś naprawdę jest przekonany o istnieniu Boga, lecz problemu, czy czyjaś wiara jest dostatecznie silna i czy ta osoba rzeczywiście pragnie żyć zgodnie $\mathrm{z}$ tym, w co wierzy ${ }^{15}$. Analogiczna próba przekonań spełniających normy epistemiczne - czy naprawdę chcę przyjąć przekonanie, że p? - to rzecz pozbawiona sensu. Wiara, co prawda, zawiera komponent propozycjonalny, ale różni się ona od przekonań tym, że pozostaje $\mathrm{w}$ intrygującej relacji z aktami woli. Relację tę można nazwać sedymentacją. Jest to stopniowe wzmacnianie przekonań podmiotu, coraz silniejsza asercja, w miarę podejmowania kolejnych aktów woli, osłabianie asercji w przypadku ich niepodejmowania.

(III) $\mathrm{Na}$ autentyczną wiarę składa się nie tylko specyficzne doświadczanie świata i uznanie pewnych przekonań dzięki aktom woli. Kolejnym jej

\footnotetext{
${ }^{15}$ Por. JUDYCKi 2014, 123-143. Judycki twierdzi, że przekonania są zależne od woli w tym sensie, że mogę zapytać samego siebie, czy jestem przekonany, że p, i odpowiedzieć twierdząco lub przecząco, co ma być właśnie aktem woli przyjmującym lub odrzucającym p, o tyle częstym, że z reguły p nie jest dla mnie oczywiste ani niezawodnie dowiedzione. Sądzę jednak, że podmiot mający dostęp do odpowiednich racji epistemicznych „nie może nic poradzić”, że jest przekonany, że p, a owo pytanie odnosi się jedynie to autorefleksji nad racjami, z powodu których je przyjął. Alternatywą jest okłamywanie samego siebie bądź oddanie się we władzę fantazji lub myślenia życzeniowego. Por. ibid., 63-64.
} 
elementem jest przeżywanie osobowej relacji z Bogiem, wyrażanej się przez intencjonalne akty, takie jak uczucia, modlitwa czy rytuał, które stają się niezrozumiałe poza założeniem, że ich adresat ma osobową charakterystykę i że realnie istnieje. Jednocześnie realne istnienie drugiego podmiotu nie wystarcza, aby o niej mówić. Relacja między osobami zachodzi dopiero w kontekście uczuć, potrzeb, zaufania, zainteresowania i tak dalej (lub przeciwieństw). Żaden $\mathrm{z}$ tych kontekstów nie pojawia się wyłącznie w wyniku przekonania o istnieniu drugiej osoby, które może być tylko formalną ramą, warunkiem koniecznym, ale niewystarczającym dla istnienia relacji. Jednocześnie nie mogę doświadczyć relacji z drugą osobą, o ile nie jestem zarazem przekonany, że ona rzeczywiście istnieje jako drugi człon tej relacji.

Intelektualistyczny i antyintelektualistyczny model wiary są konsekwencją specyficznego kontekstu teoretycznego, który w inspiracji uwagami Lindy Zagzebski możemy nazwać oświeceniowym paradygmatem epistemologicznym. Możemy go zrekonstruować jako przyjęcie (na poziomie metaprzedmiotowym) dla danej dziedziny dyskursu przesłanek i wniosku następującego rozumowania:

(a) Uzasadnienie praktyki X (np. aktów religijnych) zależy od uzasadnienia przekonań o X (np. przekonań religijnych)

(b) Uzasadnienie przekonań o X zależy od uzasadnienia teorii X-a (np. teizmu)

(c) Uzasadnienie teorii $\mathrm{X}$-a zależy od podania argumentacji wychodzącej z przesłanek, które może zaakceptować każdy zwyczajny człowiek, bez zakładania specjalnego rodzaju doświadczenia lub dodatkowych przesłanek $\mathrm{z}$ autorytetu

Gdy dodamy jeszcze jedną przesłankę:

(d) Dla dziedziny X nie istnieją przekonujące argumenty uzasadniające teorię X-a, które wychodziłyby od przesłanek, które może zaakceptować każdy zwyczajny człowiek, bez zakładania specjalnego rodzaju doświadczenia lub dodatkowych przesłanek z autorytetu

otrzymamy stanowisko sceptycyzmu dziedzinowego dla X (ZAGZEBSKI 2011, 394-398). Przy tym antyintelektualizm to rewers bądź konsekwencja paradygmatu oświeceniowego: skoro wiara nie spełnia przedłożonych standardów, to w ogóle nie ma żadnego aspektu propozycjonalnego i jest dziedziną arbitralnej praktyki bądź ma czysto fideistyczny charakter. Źródłami oświeceniowego paradygmatu są, zdaniem Lindy Zagzebski, fundacjonalizm i ega- 
litaryzm połączone z wrogością wobec tradycji (via Kartezjusz). Przedstawiam w uogólnionej formie rozumowanie, które Zagzebski podaje dla filozofii religii, ponieważ warto zauważyć, że ów paradygmat jest obecny także w innych dziedzinach filozofii i sprawia rozmaite problemy teoretyczne, dotyczące choćby kognitywnego wymiaru emocji i uczuć, statusu wiedzy praktycznej czy przekonań pochodzących z autorytetu, tradycji lub świadectwa.

Jeżeli przedstawiona argumentacja jest poprawna i wskazuje na silny związek między praktycznym i propozycjonalnym komponentem wiary, to wymyka się ona omawianym modelom i oświeceniowej epistemologii, gdyż nie można analizować jej poszczególnych składników w izolacji od pozostałych. Należy zatem zapytać, jak mamy ją rozumieć? Jedną z dróg, która może zaprowadzić nas do znalezienia odpowiedzi, będzie przyjrzenie się zjawisku o pokrewnych cechach, wobec którego dysponujemy adekwatnym modelem teoretycznym, który może przekonująco opisać i wyjaśnić takie własności, jak zdolność do transformacji doświadczenia, zależność uznawanych przekonań od aktów woli czy też relacyjny charakter. Pozwoli nam to na sformułowanie teoretycznego modelu wiary per analogiam. W moim przekonaniu tym zjawiskiem jest moralność, a modelem — pojęcie cnoty ${ }^{16}$.

2.

XX wiek był czasem ożywionych dyskusji metaetycznych. Dotyczyły one fundamentalnych kwestii: interpretacji doświadczenia moralnego, analizy funkcji dyskursu moralnego, natury sądów moralnych, statusu ontycznego „faktów moralnych” czy zagadnienia motywacji moralnej. Jedną z głównych opozycji, jakie zarysowały się w tych dyskusjach, był spór kognitywizmu $\mathrm{z}$ antykognitywizmem. Koncentrował się on na pytaniu, czy przekonania moralne mogą być interpretowane jako stany kognitywne. Alternatywę stanowiło uznanie, że pełnią raczej funkcję ekspresywną. Wybór ten był dość kłopotliwy. Z jednej strony, doświadczenie moralne zależy od czynników pozapoznawczych, takich jak uwarunkowania psychologiczne, społeczne, kulturowe i historyczne, które utrudniają jego kognitywistyczną interpretację. Z drugiej strony, wyrażające to doświadczenie przekonania moralne prima facie wydają się niewiele różnić od innych przekonań, które w niekontrowersyjny sposób możemy uznać za stany kognitywne. W przekonaniach moralnych zbiega się aspekt teoretyczny i praktyczny, co stanowi

\footnotetext{
${ }^{16}$ Przedstawiona propozycja nie nawiązuje bezpośrednio do św. Tomasza, który wiarę traktował jako cnotę nadnaturalną (wlaną). Zob. DAVIES 1992, 274-285.
} 
trudność zarówno dla ich kognitywistycznej, jak i antykognitywistycznej interpretacji. W konsekwencji tej dyskusji stwierdzono, że potrzebne są nowe teoretyczne modele ludzkiego funkcjonowania moralnego, które lepiej oddadzą teoretyczno-praktyczną naturę moralności. Była to jedna z przyczyn powstania współczesnej etyki cnót ${ }^{17}$. O deskryptywnej i eksplanacyjnej użyteczności pojęcia cnoty może świadczyć to, że chociaż współczesna etyka cnót rodziła się w opozycji do konsekwencjalizmu i dentologizmu, przedstawiciele tych nurtów wypracowali w toku dyskusji własne teorie cnót. Co więcej, pojęcie cnoty zostało przyjęte $\mathrm{w}$ innych dziedzinach filozofii, na przykład w epistemologii (SzUTTA 2017, 48-53). Ze względu na zróżnicowanie współczesnych teorii cnót (CRISP 2010, 21-38) nie można w prosty sposób przenieść pojęcia cnoty na grunt filozofii religii. Dlatego tutaj koncentruję się na jednym z zaproponowanych ujęć - na nawiązującej do myśli Arystotelesa rozwojowej (ang. developmental) teorii cnót autorstwa Julii Annas $(2011,1-7,21)$, posiłkując się narzędziami wypracowanymi przez innych reprezentantów tego nurtu. Moim celem nie jest szczegółowe przedstawienie tej teorii, lecz zastosowanie pojęcia cnoty do analizy zjawiska wiary.

Annas proponuje, aby cnotę interpretować przez analogię do naszego rozumienia umiejętności praktycznych, akcentując proces ich nabywania i rozwoju. Podstawową przesłanką jest tutaj to, że zarówno cnota, jak i umiejętność to zdolności praktyczne, których nie można nabyć przez poznanie teoretyczne, lecz jedynie poprzez racjonalnie kierowany proces zdobywania praktycznego doświadczenia (ANNAS 2011, 1-7, 21). Rekonstruując wywód Annas, posłużę się bliskim mi przykładem nauki gry w szachy, który nie pojawia się w tekście autorki (odwołuje się ona m.in. do gry na pianinie i budownictwa), ale wydaje się trafnie oddawać jej intuicje. W jaki zatem sposób powinniśmy rozumieć umiejętności?

Umiejętności należy odróżnić od wrodzonych predyspozycji i kapitału społecznego. Przed przystąpieniem do nauki gry w szachy możemy już mieć wrodzone lub nabyte zasoby, które ułatwią naukę lub umożliwią opanowanie

\footnotetext{
${ }^{17}$ Zazwyczaj twierdzi się, że przyczyną restauracji etyki cnót było niezadowolenie z aporii i trudnych konsekwencji konsekwencjalistycznych i deontologicznych teorii etycznych. Warto jednak zwrócić uwagę na to, że owo niezadowolenie dotyczyło również narzędzi konceptualnych, dzięki którym interpretowano sferę moralności, a były to takie pojęcia jak przekonanie, obowiązek, norma, prawo moralne, wina moralna czy teoria etyczna. Ich wybór wynikał z pewnych rozstrzygnięć metaetycznych. Alternatywą (bądź konsekwencją) takiego podejścia było przekonanie, że moralność wymyka się kategoriom racjonalnym. Stąd etyka cnót jako via media: koncepcja, które oddaje sprawiedliwość unikatowej naturze praktycznej racjonalności. Zob. MiLLER 2003, 1-7 nn.; ANSCOMBE 1958, 1-19; FoOt 2002, 1-18; MACINTYRe 1996, 21-154; Williams 1985, 1-21 nn.; SzUTTA 2017, 27-53.
} 
umiejętności na wysokim poziomie. Nasi rodzice, na przykład, mogli zapewnić nam możliwość regularnej nauki, w której pomocne były wysoka inteligencja obliczeniowa i brak wybuchowego temperamentu. Predyspozycje te nie oznaczają jednak posiadania umiejętności i nie determinują naszych osiągnięć. Niezależnie od nich każdy adept musi podjąć wysiłek kontynuowania nauki i pokonywania przeszkód w tracie swojego rozwoju, a ogromny talent może być zmarnowany (Fоот 2002, 10-11; SzUTTA 2017, 100-101).

Naukę gry w szachy można zacząć w różnym wieku. Zawsze jednak nauka ma miejsce w pewnym kontekście społeczno-kulturowym ${ }^{18}$ : uczeń jest już jakoś ukształtowany jako podmiot, nabył i zaczął rozwijać inne umiejętności, charakter, system potrzeb i motywacji, kapitał kulturowy, co więcej - uczy się dzięki drugiemu człowiekowi, najczęściej w ramach relacji mistrz-uczeń. Pierwszy etap nauki polega na przyswojeniu podstawowych zasad, które odbywa się poprzez mechaniczne powtarzanie. Chodzi tutaj o reguły poruszania się bierkami, warunki możliwych zakończeń rozgrywki (wygrana, przegrana, remis), pozycje ważne z racji tych zakończeń (szach, szach-mat, pat) oraz kilka bardziej zniuansowanych zasad (roszada, bicie w przelocie, promocja piona). Zakończenie tego etapu to za mało, aby móc o kimś orzec, że nauczył się gry w szachy. Częstą sytuacją w trakcie nauki (zwłaszcza u dzieci) jest to, że adept próbuje wygrać rozgrywkę wykonując posunięcia będące lustrzanym odbiciem posunięć nauczyciela, co niemal nigdy nie kończy się zwycięstwem, ale mówi coś o sposobie, w jaki uczymy się nowych umiejętności. Uczeń na tym poziomie nie opanował jeszcze wymiaru gry, który można nazwać architekturą gry, jego gra nie jest inteligentna. Znajomość bazowych reguł określa ramy gry, lecz niedostatecznie determinuje korzystne strategie, posunięcia, które przybliżają do wygranej, a przez to są racjonalnie uzasadnione (ANNAs 2011, 21-23).

Racjonalność i twórcza inteligencja są konieczne na kolejnym etapie nauki, na którym uczeń przyswaja bardziej złożone aspekty gry, takie jak ocena wartości bierek, reguły obrony i ataku, otwarcia, gambity czy atak krzyżowy. Poziom ten jest trudny do opanowania $z$ dwóch powodów. Po pierwsze, ogólne reguły dotyczące tych aspektów muszą być interpretowane kontekstualnie, nie można ich stosować mechanicznie, ponieważ liczba możliwych pozycji powoduje, że każda partia jest w zasadzie unikatowa

\footnotetext{
${ }^{18}$ Kontekst społeczno-kulturowy ma różny charakter, nie w każdych okolicznościach (Trzeci Świat) łatwo rozwinąć umiejętność gry na pianinie. W demoralizującym otoczeniu trudno o rozwój cnót. ANNAS 2011, 29-31. Interesujące jest to, że demoralizujące otoczenie może być i często jest żyzną glebą dla wiary.
} 
(przynajmniej dla ucznia). Po drugie, taka gra wymaga przeprowadzania złożonych rachunków, ocierających się o granice indywidualnych zdolności obliczeniowych (ANNAS 2011, 21-24). Z tych powodów istotny staje się aspekt motywacyjny. Trudniejsze aspekty rozgrywki wymagają od ucznia silnej motywacji do nauki, panowania nad uczuciami i cierpliwości oraz zdolności do podtrzymywania uwagi, bez których analiza złożonych sytuacji wywoła zniecierpliwienie zakończone chaotycznym, odruchowym posunięciem, które w wielu wypadkach będzie błędne (ANNAs 2011, 24-25).

O kimś, kto opanował grę w szachy na tym poziomie, możemy powiedzieć, że nabył umiejętność gry w szachy. Warto zauważyć, że nie przyswoił umiejętności, która ma bierny, automatyczny charakter. Wymusza to nie tylko natura gry, lecz także to, że mechaniczne stosowanie reguł (na przykład wymiana figur o zbliżonej wartości, niezależnie od pozycji) jest strategią zawodną i łatwą do przewidzenia. Rozwój umiejętności wymaga więc nie tylko znajomości zasad i regul, lecz także permanentnego stosowania twórczych rozwiązań do napotkanych sytuacji, doświadczenia wielu różnych rozgrywek. Ponadto, jeżeli założymy, że szachy są grą otwartą (a tak wydaje się być, gdy bierzemy pod uwagę ludzkich przeciwników), to nie ma poziomu, którego opanowanie kończy naukę. Zrozumienie ogólnych reguł na pewnym poziomie zaawansowania przenosi konieczność stosowania twórczych i inteligentnych rozwiązań na poziom wyżej (SzUTTA 2017, 107-111; ANNAS 2011, 24-26).

Warto dodać dwie ważne obserwacje. Po pierwsze, umiejętności mają samoistną tendencję regresywną. Jakkolwiek gracz, który nie praktykuje, zachowuje pewien poziom umiejętności, to brak praktyki, zatrzymanie się na pewnym poziomie rozwoju i wyłączenie z gry twórczej inteligencji są tożsame ze spadkiem formy, a więc pogorszeniem się umiejętności (ANNAS 2011, 1720). Po drugie, rozwój nauki w istotny sposób przekształca perspektywę poznawczą adepta szachów. Mam na myśli nabycie zdolności percepcji złożonych „faktów szachowych”, które dla nowicjusza są „przezroczyste”, są niewidoczne i tracą wpływ na grę. Podam tutaj dwa przykłady. Pierwszym będzie związanie, czyli sytuacja, w której dana bierka jest zablokowana i nie może (lub nie powinna) wykonać ruchu, ponieważ jego konsekwencją jest strata lub pozycja niezgodna z zasadami (np. biały król będzie szachowany w wyniku ruchu białej figury). Drugim zaś roszada Pama-Krabbégo (roszada w linii pionowej po promocji piona), która aż do decyzji Międzynarodowej Federacji Szachowej z 1972 r. była w pełni poprawnym ruchem, a z perspektywy początkującego jest bardzo nieintuicyjna (ANNAs 2011, 38-39). 
Z powyższego opisu procesu nabywania i doskonalenia umiejętności można wywnioskować, że umiejętność ma następujące, kluczowe własności:

(A) Jest dyspozycją wymagającą wysiłku w celu jej nabycia, podtrzymania i rozwoju, nie można jej rozumieć jako wrodzonego talentu (predyspozycji)

(B) Nauka umiejętności odbywa się w kontekście społecznym

(C) Nie może być rozumiana jako rutynowe wykonywanie działań

(D) Jej rozwój wymaga praktycznego doświadczenia i stałego zaangażowania twórczej inteligencji

(E) Nie istnieje kres jej rozwoju

(F) Posiadanie umiejętności $\mathrm{w}$ istotny sposób przekształca perspektywę poznawczą i emocjonalną

Według Annas podobne cechy przysługują cnotom. Należy mieć na uwadze, że umiejętność i cnota nie są tożsame, pomimo istotnych podobieństw różnią się od siebie. Różnice te nie są jednak aż tak ważne z perspektywy tezy niniejszego tekstu, poza pewnymi, które zostaną wspomniane dalej (Szutta 2017, 101-106). Spróbuję teraz przeprowadzić łącznie podwójną analogię między umiejętnością a cnotą z jednej strony, z drugiej zaś cnotą i wiarą. Przyjmę, że wiara tak jak cnota jest relatywnie stałą, kognitywno-afektywną dyspozycją, która reorientuje jednostkę na w tym wypadku dobro religijne. Jeżeli to podejście jest trafne, model aretologiczny pozwoli na opis i wyjaśnienie istotnych cech wiary, zwłaszcza tych, które sprawiają problemy alternatywnym modelom (Szutta 2017, 111-125) ${ }^{19}$.

Cnoty i wiara są nabywane społecznie, a rzadko (nigdy?) w wyniku teoretycznego namysłu (ANNAS 2011, 21-22) ${ }^{20}$. Ich źródłem może być proces wychowawczy, przełomowe spotkanie, naśladowanie, uczucie podziwu bądź świadectwo, tak czy owak mechanizm zachodzący $w$ ramach relacji międzyludzkich ${ }^{21}$. Nabycie i wstępny rozwój takiej dyspozycji nie muszą być świadome, ale nie oznacza to, że pozostaje ona nieświadoma i bierna czy też można ją utożsamić z samorzutnie, „mechanicznie” rozwijającą się cechą. Być może osoby, które cechuje temperamentalnie uwarunkowana ponad-

\footnotetext{
${ }^{19}$ Pomijam przy tym pytanie, czy wiara jest bliższa cnocie moralnej, intelektualnej czy innemu jeszcze gatunkowi cnoty, ponieważ przekracza to ramy niniejszego tekstu. $\mathrm{W}$ tej sprawie zob. AUDI 2014, 340-346.

${ }^{20}$ Chociaż mogą zostać utracone w wyniku racjonalnej krytyki z trzecioosobowej, obiektywnej perspektywy, jak sugeruje Bernard Williams, opisując fenomen refleksji, która niszczy wiedzę. WiLLIAMS 1985, 132-155.

${ }^{21} \mathrm{~W}$ świetle zapisów biblijnych przyczyną nawrócenia jest spotkanie z Bogiem, jego wysłannikiem bądź świadkiem (prorocy, apostołowie), na rolę podziwu w ramach swojej exemplarist moral theory zwraca zaś uwagę Linda Zagzebski (2010, 39-55); ANNAS 2011, 21-23.
} 
przeciętna wrażliwość lub skłonność do rozwagi, mają pewną łatwość w przyswojeniu wiary czy cnoty umiarkowania, ale nie ma tutaj jednoznacznej determinacji. Owe dyspozycje wymagają stałej aktywności, która podtrzymuje je i rozwija, w przeciwnym razie zamierają i tracą wpływ na funkcjonowanie jednostki ${ }^{22}$. Fakt, że często pojawiają się w naszym życiu w czasie, gdy nie jesteśmy jeszcze zdolni do kierowania nimi w świadomy sposób, nie przesądza o ich charakterze. Późniejsze rutynowe powtarzanie biernie wyuczonych czynności (uczuć bądź sądów), na przykład uczestnictwo w życiu sakramentalnym lub powstrzymywanie się od obżarstwa, prowadzi jedynie do podtrzymania „wiary martwej” lub tępego odtwarzania nawyków i nie jest cnotliwe (SzUTTA 2017, s. 107-111). O niecnotliwym charakterze bezmyślnego powtarzania decyduje jego nieinteligentny charakter. Dyspozycja pozbawiona racjonalnego charakteru i dojrzałej motywacji może rodzić negatywne skutki, mechaniczna wstrzemięźliwość doprowadzi w końcu do apatii i utraty smaku życia, podczas gdy wiara martwa skutkuje utratą autentycznego zainteresowania sferą transcendencji. Nie utożsamiamy się $\mathrm{z}$ nią i traktujemy ją jako peryferyjną, bez większego znaczenia dla naszej autoidentyfikacji. Cnota i wiara żywa są zaś głęboko zakorzenione $\mathrm{w}$ tożsamości jednostki i kierują jej aktywnością, istnieje też nieprzypadkowy związek między ich posiadaniem a dostępem do dóbr, które są ich celem (AUDI 2014, 331-333). A zatem wśród pierwszej grupy cech cnót i wiary należy wymienić: społeczny kontekst nauki, aktywny, niemechaniczny sposób działania i nieperyferyjne znaczenie dla podmiotu.

W rzeczy samej, przekazywanie wiary bądź cnót często zaczyna się od naiwnych form, mechanicznego powtarzania czy wręcz wymuszania przez opiekunów pewnego rodzaju aktywności, na przykład unikania niezdrowej żywności czy uczestnictwa w cotygodniowym nabożeństwie. Ale nauka kończąca się na tym poziomie oznacza jedynie wychowawczą porażkę. Umiarkowanie czy wiara ukształtowanej tak osoby nie mogą spełnić dwóch podkreślanych przez Annas wymogów, zaspokajania potrzeby nauki (ang. the need to learn) i dążenia do rozwoju (ang. the drive to aspire) (Annas 2011, 16-32, 36-40), przez co są niesprawne w konfrontacji z rzeczywistością i tracą zdolność generowania dobrych rozwiązań nowych sytuacji problemowych. Kluczowym aspektem rozwoju cnoty i wiary jest bowiem

\footnotetext{
${ }^{22}$ Ponadto wrodzone cechy mogą przerodzić się w dyspozycje przeciwne cnocie (wierze). Naturalna skłonność do rozwagi może przeistoczyć się w nadmiernie refleksyjne usposobienie, utrudniające podjęcie działania, z kolei przyrodzona wrażliwość może doprowadzić do zbytniego przejęcia się swoją lub cudzą grzeszną naturą i niechrześcijańskiego pesymizmu.
} 
zaangażowanie rozumu. Jeżeli jestem wprowadzany w jakąś aktywność, taką jak gra w szachy, troska o ciało i umysł czy też życie religijne, to powinienem otrzymać środki, które umożliwią mi później samodzielne i owocne działanie na tym polu, co jest możliwe tylko wtedy, gdy będę rzeczywiście rozumiał daną sferę, potrafił przed sobą i innymi uzasadnić wypowiadane sądy i podejmowane czyny. Muszę więc poznać i przyjąć jako własne specyficzne racje kierujące tą formą aktywności. Dlatego moja nauka nie może być pasywna, lecz powinna pobudzić mnie do aktywnego i samodzielnego rozwoju, dzięki któremu będę zdolny w twórczy sposób odnosić się do złożonej materii tej sfery życia praktycznego. Asysta nauczyciela ma ograniczony zakres, a dobry nauczyciel zmusza mnie w pewnym momencie do przejęcia odpowiedzialności i suwerennego kierowania własnym życiem. Nie można utrzymać i rozwijać cnoty bądź wiary bez utwierdzania i ożywiania ich kolejnymi decyzjami i działaniami, bez konfrontacji z realnym doświadczeniem egzystencjalnym, bez podejmowania prób sformułowania rozwiązań różnych trudności. Jest to możliwe dzięki zaangażowaniu kreatywnej inteligencji, która rozwija wyuczone zasoby konceptualne i poszukuje twórczych rozwiązań nowych sytuacji problemowych. Warto dodać, że tak jak w przypadku umiejętności trudno wyobrazić sobie zakończenie jej rozwoju, tak i cnoty bądź wiara nie mają postaci, które już dalej nie muszą być rozwijane - przynajmniej jak długo trwa życie podmiotu, zawsze bowiem mogą wystąpić nowe, nieprzewidziane sytuacje, wymagające kreatywnych rozwiązań (ANNAS 2011, 64-65; SzUTTA 2017, 109-111) 23. „Bo kto chce ocalić swoje życie, straci je; a kto straci swoje życie z mojego powodu, ten je ocali” ( $Ł k$ 9, 24). Kolejne kluczowe cechy cnoty i wiary to ich inteligentny, racjonalny i autotranscendentny charakter.

Wraz z zakończeniem niesamodzielnego etapu nauki cnoty czy wiary, etapu, którego nie można sprowadzić do przyswajania biernych, pozbawionych racjonalności nawyków, i przejściem na poziom samodzielnego rozwoju tych dyspozycji zmienia się pierwszoosobowa perspektywa poznawczo-afektywna podmiotu. Ani cnota, ani też wiara nie wytrzymają konfrontacji z rzeczywistością, o ile nie dysponuje odpowiednimi zasobami. Mowa tutaj, po pierwsze, o zasobach motywacyjnych, zdolności przeciwstawiania się

\footnotetext{
${ }^{23}$ Uznanie, że autotranscendencja wiary jest jej immanentnym składnikiem, pozwala odrzucić interpretację religii $\mathrm{w}$ duchu faryzeizmu, wielokrotnie piętnowaną na kartach Nowego Testamentu (m.in. Mk 7, 1-13). Mam tutaj na uwadze zarówno utożsamienie religijnej wizji dobra moralnego z postępowaniem zgodnie z społecznie akceptowanym zwyczajem, jak i sprowadzenie pobożności do uczestnictwa w rytuale religijnym (dewocja). Zob. SCHELER 1973, 27.
} 
przeciwnościom i motywom prowadzącym do pojawienia się i rozwoju wad ${ }^{24}$. Warto przy tym zauważyć, że pytanie o źródło motywacji człowieka cnotliwego lub religijnego jest bezprzedmiotowe lub trywialne. Gdy zapytamy go o przeżywane trudności, to jedyną sensowną odpowiedzią wydaje się: „chyba zaniedbałem swoją wiarę" albo „zacząłem sobie folgować”. Cnota nie generuje specjalnego rodzaju motywacji, lecz integruje i udoskonala motywację już posiadaną, relatywną do zainteresowania, jakim podmiot darzy dane dobro (ANNAS 2011, 10, 81-82). Po drugie, cnota i wiara muszą oprzeć się na naszych zdolnościach poznawczych, ale modyfikują je. Rozwijają i transformują nasze poznanie, które w coraz bardziej zniuansowany sposób odkrywa wszystkie relewantne fakty moralne czy też fakty religijne, $\mathrm{w}$ istocie trudno wyobrazić sobie, że bez wyczulenia zdolności poznawczych podmiot będzie zdolny do sformułowania przekonujących siebie i innych odpowiedzi na nowo pojawiające się i skomplikowane sytuacje problemowe. Osoba cnotliwa czy też ktoś autentycznie wierzący wraz z rozwojem tej dyspozycji zaczyna odmiennie postrzegać rzeczywistość, jego spojrzenie oddala się od spojrzenia zwyczajnej osoby, która jest areligijna bądź pozbawiona cnoty (ANNAS 2011, 38-39) ${ }^{25}$.

$\mathrm{Na}$ koniec tej części chciałbym zwrócić uwagę na istotne różnice między umiejętnościami a cnotami i wiarą, co stanowi ograniczenie pierwszej analogii, ale niekoniecznie tezy i argumentacji tekstu. Po pierwsze, umiejętności są partykularne, w przeciwieństwie do cnót (jeżeli zatrzymamy się na cnotach kardynalnych) czy wiary, które wpływają na całość życia człowieka jako człowieka. Umiejętności tylko częściowo determinują nasze życie, relatywnie do stopnia zaangażowania w konkretną aktywność, której dotyczą. Wynika to z natury dóbr, które są celem danej dyspozycji. W przypadku umiejętności są to partykularne i co do zasady instrumentalne dobra, na przykład sława czy zamożność osiągnięte dzięki pozycji mistrza szachowego bądź doskonałego architekta. Z kolei cnoty nakierowane są na dobra o fundamentalnym znaczeniu, dobra będące celem naszych najgłębszych, najsilniejszych pragnień i dążeń, dobra autoteliczne, które składają się na dobre moralnie, pomyślne, szczęśliwe i spełnione życie (ang. well-being) (ANNAS 2011, 8-12, 100-118; Fоот 2002, 2-8; SzUTtA 2017, 55-98, 101-106). W przypadku wiary dobrem-celem jest zaś osobowa relacja z Bogiem i życie

\footnotetext{
${ }^{24}$ Cnota koryguje, ponieważ polem jej aktywności jest dążenie do takich dóbr, których zdobycie utrudnia ludzka natura. FоOT 2002, 8-14.

${ }^{25} \mathrm{Na}$ tę różnicę składa się także priorytetowy charakter motywów i racji wynikających z cnoty. Zob. AUDI 2014, 336-339.
} 
wieczne (zbawienie). Tę myśl można jeszcze wyrazić tak: z perspektywy człowieka jako człowieka umiejętności nie są konieczne. Potrafimy obejść się bez gry w szachy, w istocie ograniczony czas uniemożliwia nam zaawansowany rozwój zbyt wielu umiejętności. Ponadto wiele partykularnych dóbr można zdobyć na różne sposoby, na przykład zamożność można osiągnąć zarówno w wyniku uprawiania sportu, jak i twórczości artystycznej. W przeciwieństwie do tego zainteresowanie dobrami będącymi celami cnót i wiary wynika z ludzkiej natury, a związek między nimi ma nieprzypadkowy i wewnętrzny charakter (SzuTTA 2017, 97-98). Jeżeli chrześcijaństwo mówi prawdę o świecie i słusznie przypisuje Stwórcy osobową charakterystykę, to relacja z nim jest największym możliwym do wyobrażenia dobrem, a choćby częściowe zrozumienie tego dobra i dążenie do niego możliwe są w pierwszej kolejności na drodze wiary. Podobnie (prze)trwanie wspólnoty rządzącej się rozsądnymi zasadami moralnymi, które umożliwiają zrealizowanie takiej czy innej wizji ludzkiej pomyślności, możliwe jest wtedy, gdy jej członkowie mają odpowiednie dyspozycje, czyli cnoty (WiLliams 2006, 68-75). Zauważmy przy tym, że chociaż cnoty odróżnia od umiejętności natura ich dóbr-celów i natura relacji między takim dobrem a daną dyspozycją, to wiele spośród dóbr, które są celami w jednym i drugim wypadku, ma społeczną naturę, są to dobra innych i dobra naszych relacji z nimi. Niektóre umiejętności i cnoty wprost mają na celu dobro drugiego lub dobro relacji międzyosobowej, przykładem takich dyspozycji mogą być kompetencje psychoterapeuty, cnota sprawiedliwości czy miłosierdzie. Podobnie wiara ogniskuje się wokół relacji z Bogiem i bliźnimi. Klasyczny zarzut egoizmu, który formułuje się przeciwko etyce cnót, wydaje się więc niekoniecznie sprawiedliwy, a model aretologiczny potrafi wyjaśnić, dlaczego wiara może być podobna cnocie i jednocześnie konstytuować relację z osobą ${ }^{26}$.

Po drugie, umiejętności są moralnie neutralne, mogą być użyte zarówno w dobrych, jak i złych celach. Nawet w przypadku gry w szachy możemy sobie wyobrazić sytuację moralnie nagannego użycia tej umiejętności: będzie to kochający tę grę dyktator, który lubi rozgrywać partię ze swoimi ofiarami, gdzie nagrodą za wygraną jest wolność, a karą za przegraną bolesna śmierć. Wydaje się, że cnót i wiary nie można użyć w nikczemnym celu, chociaż jest to nieco zawiła kwestia. O ile trudno podać przykład negatywnego moralnie działania umiarkowanego (chociaż być może tak należy rozumieć umiarkowanie biorące się z zgorzknienia, pewną formę purytanizmu),

${ }^{26}$ Niektóre cnoty mogą jednocześnie służyć wielu celom. FOOT 2002, 2-3; AUDI 2014, 331333, 339-340, 343. 
to jest to możliwe w przypadku odwagi, a jedną z kontrowersyjnych cech wiary jest to, że może być motywem prześladowań, wykluczenia czy nawet zabójstwa, na co dowody podaje historia. Sądzę, że związek wiary z czynami moralnie nagannymi jest przypadkowy, ale problem ten nie jest przedmiotem tego tekstu, dlatego odpowiem skrótowo: Tak jak o odważnym złoczyńcy możemy powiedzieć, że zachował się odważnie, lecz jego odwaga nie jest w nim cnotą przez brak związku z rozumnie pojętą pomyślnością, tak też religijnego fanatyka czy inkwizytora możemy uznać za osobę religijną, lecz jego wiara nie jest autentyczna, nie jest w nim cnotą przez brak silnego związku z rozumnie pojętym dobrem religijnym, czyli relacją z Bogiem i zbawieniem. Chyba, że ktoś upierałby się, że Bóg, który przedstawia się jako miłość i oczekuje od nas miłości do bliźnich, pochwala fanatyzm i stosy $(1 \mathrm{~J} 4,7-21)^{27}$.

Z perspektywy rozwojowej teorii cnoty możemy więc opisać i wyjaśnić wiarę kompetentnych osób wierzących, wiarę żywą. Własności wiary, które sprawiają trudności modelom alternatywnym, płynnie wpisują się w model aretologiczny. Podobieństwo wiary do cnoty pozwala zrozumieć, dlaczego wiara jest zależna od wysiłku woli, może modyfikować poznanie podmiotu i ma charakter relacji między osobami. Mimo tych zalet warto zapytać o słabe punkty tego modelu.

3.

W ostatniej części odniosę się do dwóch zarzutów wobec przedstawionej propozycji. Według pierwszego przekonanie, że nie ma neutralnej perspektywy, pozwalającej badać zjawiska religijne i poddawać wiarę krytycznej analizie, przekonanie, które wyraziłem, twierdząc, że wiara może modyfikować doświadczenia podmiotu i jest to niezrozumiałe poza kontekstem inteligentnej praktyki (rozwoju wiary), z konieczności prowadzi do relatywizmu, sądu, że wszystkie przekonania zakorzenione w doświadczeniu religijnym są równie (bez)zasadne ${ }^{28}$. Istnieje bowiem wiele religii, a doświadczenie religijne ich wyznawców wzajemnie się wyklucza. Wydaje się to niedorzeczne, jeżeli weźmiemy pod uwagę roszczenia do prawdziwości (chyba) każdej z nich. Zarzut ten jest oparty na petitio principii, ponieważ

\footnotetext{
${ }^{27}$ Ten problem jest pewną formą zagadnienia jedności cnót, które przekracza jednak ramy niniejszego tekstu. Na ten temat zob. FOOT 2002, 14-18.

${ }^{28}$ Jest to zarzut Prof. Ziemińskiego z dyskusji, o której wspominam w pierwszym przypisie, chociaż wtedy nie użyłem pojęcia cnoty. Co ciekawe, zarzut ten pokrywa się ze sztandarowym argumentem przeciwko etyce cnót. Zob. ZIEMIŃSKI 2016, 159-165; ANNAS 2011, 53-65.
} 
można go sformułować jedynie z perspektywy oświeceniowej epistemologii, która jest przecież przedmiotem sporu. Ale nawet pozostając w jej ramach, można zaryzykować tezę, że każda religia nieświadomie realizuje podział pracy epistemicznej, stanowi coś na kształt zespołu badawczego rzeczywistości nadprzyrodzonej. Każdy taki zespół może poznać jedynie pewien wycinek tej rzeczywistości, lecz przekonanie o prawdziwości przynajmniej rdzenia własnej doktryny jest pożądane jako warunek regulujący dalszą aktywność.

Niemniej zarzut ten pozostaje w mocy tylko wtedy, gdy religie są strukturami zamkniętymi. W takim wypadku (a) obserwacja, że przyjmuję daną religię $\mathrm{w}$ konsekwencji przygodnych okoliczności, ukształtowania mojej tożsamości właśnie przez tę tradycję, jest nie do pogodzenia z (b) przekonaniem, że doświadczenie religijne ma wartość epistemiczną, okazuje się ono raczej rezultatem trafu. Zarzut ten traci siłę, gdy uznamy, że tradycje są zdolne do autotranscendencji. Według Lindy Zagzebski ludzka racjonalność ma charakter immanentno-transcendentny. Jesteśmy gatunkiem funkcjonującym $\mathrm{w}$ ramach kultury, a więc $\mathrm{z}$ racji naszej natury poznajemy rzeczywistość dzięki kulturowo zakorzenionym standardom epistemicznym. Doj-

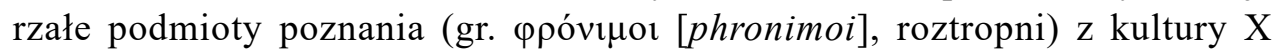
nie mogą jednak przytomnie przyjąć epistemicznego imperializmu. Dostrzegają, że w innych kulturach również jest obecne dążenie do racjonalności, są świadomi, że w wyniku odmiennego splotu okoliczności, gdyby narodzili się $\mathrm{w}$ innym miejscu i żyli w innej kulturze, przyjęcie standardów kultury Y okazałoby się dla nich racjonalne (ZAGZeBSKi 1999, 177-194). MacIntyre twierdzi z kolei, że tradycje ścierają się ze sobą w ramach historii. Tradycja zamknięta nie może ewoluować, a więc z konieczności nie może być sprawnym „narzędziem” porządkowania rzeczywistości. W chwili konfrontacji z inną tradycją nie ma zasobów intelektualnych, umożliwiających krytyczny wgląd we własne założenia i niezbędne modyfikacje. Możemy sobie wyobrazić inną możliwość. Konkretna tradycja jest otwarta, w konfrontacji z konkurentem dysponuje własnymi zasobami, które pozwalają na rewizję przekonań i ocen, a dzięki temu na przetrwanie i rozwój (MacInTYre 1988, 1-11). Annas natomiast odwołuje się do filozofii stoickiej. Chociaż stoicy wywodzili się z kontekstu społeczno-kulturowego, w którym niewolnictwo było akceptowane, okazali się zdolni do rewizji własnej tradycji i przynajmniej częściowego odrzucenia jej niemoralnych elementów (ANNAS 53-65). Etycy cnót wyrażają zatem przekonanie, że racjonalność jest zawsze zanurzona w konkretnej formacji kulturowej, ale zarazem jest zdolna do jej transcen- 
dencji. Jeżeli możliwa jest teoria racjonalności, która zachowa oba te wymiary, to dzięki niej będziemy w stanie sformułować przekonującą interpretację podstawowych kategorii epistemicznych poza oświeceniową epistemologią i zgodnie z koncepcją cnót. W konsekwencji zarzut relatywizmu straci rację bytu.

Drugi zarzut głosi, że rozumienie wiary przez pryzmat cnót opisuje i wyjaśnia tylko ortopraksję. Sztandarowa forma doświadczenia religijnego, czyli mistyka, dramatyczne nawrócenia, takie jak historia Szawła, czy też tradycyjne przekonanie, że wiara jest łaską, są niezrozumiałe na gruncie zaproponowanego modelu ${ }^{29}$. Jest to zarzut poważny. Na pierwszy rzut oka nie widać przestrzeni dla oddziaływania transcendencji, jeżeli model aretologiczny pozwala przekonująco opisać i wyjaśnić zarówno przyjęcie wiary, jak i jej dynamiczny rozwój. Tak jednak nie jest i odpowiem na ten zarzut przez ciąg uwag. Po pierwsze, przekonanie, że wiara jest łaską, jest problematyczne także dla konkurencyjnych ujęć. Skoro bowiem wiarę traktuje się jako wybór egzystencjalny albo jako władzę nabywania przekonań, to biorąc pod uwagę, o jaką stawkę toczy się ta gra, byłoby czymś wyjątkowo niepojętym ze strony Boga, aby wybór lub przekonania potrzebne do zbawienia oferować jedynie niektórym. Pojawia się tutaj druga strona tego samego zarzutu: koncepcje te w niedostateczny sposób opisują i wyjaśniają ludzką rolę w relacji z Bogiem, tak jak koncepcja aretologiczna (być może) niedostatecznie uwzględnia rolę Boga. Po drugie, odrzucam paradygmat oświeceniowy, ale jestem świadom, że filozofia pozostaje refleksją opartą na naturalnych źródłach poznania, rozumie i doświadczeniu. Wiara zatem jest tajemnicą, gdy zastanawiamy się nad zależnością między czynnikiem ludzkim i boskim, a tajemnicę tę potęguje fakt, że obie strony relacji są wolne i racjonalne. Niemniej, koncepcja aretologiczna jest zdolna do uchwycenia tego, co dostępne dla naturalnych źródeł poznania. Można to wyobrażać sobie tak, że podmiot kultywuje wiarę-cnotę rozumianą jako rama lub szkielet, w które wlewana jest treść nadprzyrodzona. Po trzecie, według teorii rozwojowej cnota nie jest rozumiana jako zdolność bezmyślnego, rutynowego powtarzaniem pewnych działań. Cnota musi mieć element kognitywny, zdolność do rozeznawania racji i dostrzegania relewantnych faktów. Na przykład trudno uznać kogoś za miłosiernego, jeżeli nie potrafi dostrzec faktów moralnych, które determinują daną sytuację jako przestrzeń wymagającą miłosierdzia. Podobnie trudno przyjąć, że istnieje ortopraksja, która nie jest $\mathrm{w}$ zasadzie wiarą martwą, jeżeli miałaby to być praktyka po-

\footnotetext{
${ }^{29}$ Autorami tego zarzutu są Prof. Piotr Gutowski (KUL) i Prof. Nina Gładziuk (PAN).
} 
zbawiona aspektu kognitywnego. Warto również dodać, że prezentowana koncepcja nie łączy się w konieczny sposób z jakąś metaprzedmiotową teorią natury „faktów moralnych” czy też „faktów wiary”. Możemy, zachowując spójność, uznać, że człowiek miłosierny dostrzega to, co sprawia, że ktoś potrzebuje pomocy, a jednocześnie przyjąć konstruktywizm czy projektywizm w metaetyce. Zaproponowana koncepcja analogicznie zakłada konieczny związek poznawczego i praktycznego komponentu wiary, ale nie przesądza, czy doświadczana przez wierzącego „rzeczywistość nadprzyrodzona" musi podlegać metafizycznie realistycznej interpretacji. Filozoficzna refleksja nad wiarą powinna odbywać się w hipotetycznym trybie „jak gdyby”, wymuszonym ograniczeniem filozofii do naturalnych źródeł poznania, ale $\mathrm{w}$ ramach tego podejścia należy wiernie oddawać to, co podlega opisowi i wyjaśnieniu. W moim przekonaniu warunek ten spełnia model aretologiczny.

\section{REFERENCJE}

ADAMS, Robert. 1987. The Virtue of Faith. Oxford: Oxford University Press.

ANNAS, Julia. 2011. Intelligent Virtue. New York: Oxford University Press.

ANSCOMBE, Gertrude Elizabeth Margaret. 1958. „Modern Moral Philosophy”. Philosophy 33: 1-19.

AudI, Robert. 2014. „Faith as Attitude. Trait, and Virtue”. W: Craig A. BoYD, Kevin Timpe (eds.). Virtues and Their Vices, 327-347. Oxford: Oxford University Press.

CRISP, Roger. 2010. „Virtue Ethics and Virtue Epistemology”. W: Heather BATTALY (ed.). Virtue and Vice, Moral and Epistemic, 21-38. Bangalore: Wiley-Blackwell.

DAvies, Brian. 1992. The Thought of Thomas Aquinas. Oxford: Clarendon Press.

DAvies, Brian. 2006. Wprowadzenie do filozofii religii. Przełożył Wacław J. Popowski. Warszawa: Prószyński i S-ka .

Foot, Philippa. 2002. Virtues and Vices and Other Essays in Moral Philosophy. Oxford: Clarendon Press.

Hume, David. 1962. Dialogi o religii naturalnej. Naturalna historia religii. Przełożyła Anna Hochfeld. Warszawa: PWN.

James, William. 1996. Prawo do wiary. Przełożył Adam Grobler. Kraków: Wydawnictwo Znak.

JUDYCKI, Stanisław. 2014. Ksiązeczka o człowieku wierzącym. Kraków: Fundacja „Dominikańskie Studium Filozofii i Teologii".

Katechizm Kościoła Katolickiego [= KKK]. 1994. Poznań: Pallotinum.

KennY, Anthony. 1992. What is Faith? New York: Oxford University Press.

KoŁAKOwSKI, Leszek. 1990. Jeśli Boga nie ma... Warszawa: Wydawnictwo Brama.

MacInTYre, Alasdair. 1996. Dziedzictwo cnoty. Przełożył Adam Chmielewski. Warszawa: Wydawnictwo Naukowe PWN.

MaCInTYRE, Alasdair. 1964. „Is Understanding Religion Compatible with Believing?”. W: John Hick (ed.). Faith and Philosophers, 115-133. New York: Palgrave Macmillan.

MacIntyre, Alasdair. 1988. Whose Justice? Which Rationality? Notre Dame: University of Notre Dame Press. 
Miller, Alex. 2003. An Introduction to Contemporary Metaethics. Cambridge (UK): Polity Press.

Moser, Paul K. 2016. „Reason and Faith in God”. Roczniki Filozoficzne 64, 4: 5-20.

Pismo Święte Starego i Nowego Testamentu. 2009. Częstochowa: Edycja Świętego Pawła.

Plantinga, Alvin, i Nicholas Wolterstorff (eds.). 2004. Faith and Rationality. Notre Dame: University of Notre Dame Press.

Scheler, Max. 1973. Formalism in Ethics and The Non-Formal Ethics of Values. Przełożyli Manfred S. Frings i Roger L. Funk. Evanston: Northwest University Press.

SzuTTA, Natasza. 2017. Czy istnieje coś, co zwiemy moralnym charakterem i cnota? Lublin: Wydawnictwo Academicon.

Williams, Bernard. 1985. Ethics and the Limits of Philosophy. London: Fontana Press.

Williams, Bernard. 2017, „Filozofia jako dyscyplina humanistyczna”. Przełożył Paweł Pijas. Roczniki Filozoficzne" 65, 4: 325-350.

Williams, Bernard. 2006. Philosophy as a Humanistic Discipline. Edited by Adrian W. Moore. New Jersey: Princeton University Press.

Williams, Bernard. 2003. Truth and Truthfulness. An Essay in Genealogy. Princeton: Princeton University Press.

Wittgenstein, Ludwig. 1967. Lectures and Conversations on Aesthetics, Psychology and Religious Belief. Edited by Cyril Barrett. Los Angeles: University of California Press.

ZAGZEBSKI, Linda. 1999. „Phronesis and Christian Belief”. W: Godehard BRÜNTRUP i Ronald K. TACELLI (eds.). The Rationality of Theism, 177-194. Dordrecht: Springer Science + Business Media.

ZAGZEBSKI, Linda. 2010. „Exemplarist Moral Theory”. W: W: Heather BATTALY (ed.). Virtue and Vice, Moral and Epistemic, 39-55. Bangalore: Wiley-Blackwell.

ZAGZEBSKI, Linda. 2011. „Religious Knowledge”. W: Sven BERNECKER i Duncan PrITCHARD (eds.). The Routledge Companion to Epistemology, 394-398. New York: Routledge.

ZIEMIŃSKI, Ireneusz. 2013. „Filozofia religii jako droga do sceptycyzmu”. Studia Religiologica 46, 4: $263-273$.

ZIEMIŃSKI, Ireneusz. 2014. „Kryzys chrześcijaństwa z perspektywy filozofii religii”. Filo-sofija 25, 2: 109-138.

ZIEMIŃSKI, Ireneusz. 2016. „Kryzys chrześcijaństwa z perspektywy filozofii religii - odpowiedzi Polemistom". Filo-sofija 33, 2: 153-181.

\section{ARETOLOGICZNA INTERPRETACJA \\ (CHRZEŚCIJAŃSKIEJ) WIARY RELIGIJNEJ}

Streszczenie

W artykule argumentuję, że model aretologiczny jest trafnym modelem (chrześcijańskiej) wiary religijnej. Rozpoczynam od przedstawienia dwóch konkurencyjnych i skrajnych modeli obecnych w filozofii religii, które określam jako model intelektualistyczny i antyintelektualistyczny. Następnie staram się pokazać pewne podstawowe własności fenomenu wiary religijnej, które są przez te modele ignorowane, co stanowi poważną trudność teoretyczną dla całej filozofii religii. Przedstawiam model aretologiczny jako możliwą alternatywę, bazując na rozwojowej (developmental) teorii cnoty autorstwa Julii Annas i innych narzędziach wypracowanych przez przedstawicieli współczesnej etyki cnót. Trzon argumentacji zakłada podobieństwo wiary religijnej i moralności, a przez to problematyki filozofii religii i etyki. 


\section{ARETOLOGICAL INTERPRETATION \\ OF THE (CHRISTIAN) RELIGIOUS FAITH}

\section{S u m m a r y}

I argue that an aretaic model is apt for (Christian) religious faith. I begin with a presentation of two rival and radical models of faith present in philosophy of religion, which I label as, respectively, "intellectual" and "anti-intellectual" model. Then, I try to show some essential characteristics of faith that are ignored by these models, which results in a serious theoretical difficulty for philosophy of religion. I present the aretaic model as a convincing alternative, using Julia Annas' developmental theory of virtue and some other conceptual tools provided by representatives of contemporary virtue ethics. The core of the argumentation presumes that religious faith and morality are similar, thus also the issues of philosophy of religion and ethics are similar.

Słowa kluczowe: wiara; filozofia religii; cnota; Julia Annas.

Key words: faith; philosophy of religion; virtue; Julia Annas.

Information about Author: PAwet PIJAS, PhD - Assistant Professor at the Department of the History of Ancient, Medieval and Modern Philosophy, Institute of Philosophy, Sociology and Journalism, University of Gdańsk, a graduate of the College of MISH KUL and the Faculty of Philosophy of the Catholic University of Lublin; address for correspondence - e-mail: pawel. pijas@ug.edu.pl. ORCID: https://orcid.org/0000-0002-7694-7482. 